\title{
The Guaniamo diamond region, Bolivar state, Venezuela: a new kimberlite province
}

\author{
Channer, D. M. DeR. ${ }^{1}$, Cooper R. E. C. ${ }^{1}$, and Kaminsky, F. ${ }^{2}$
}

1. Guaniamo Mining Company, Centro Gerencial Mohedano, Cruce Av. Mohedano, Urb. La Castellana. Caracas. Venezuela

2. KM Diamond Exploration Ltd. 815 Evelyn Drive, West Vancouver, BC V7T 1J1 Canada

\section{Introduction}

Traditionally, Venezuelan alluvial diamonds were thought to have been derived from the Proterozoic Roraima formation, which forms a series of table mountains across the southern part of Venezuela (Reid, 1974). The discovery of a diamondiferous ultramafic rock in the Guaniamo alluvial diamond field in 1982 by J. Drew, R. Cooper, and R. Baxter - Brown cast doubt on this theory, at least for the Guaniamo region. Guaniamo Mining Company, in the course of its exploration for kimberlite pipes in the Guaniamo region, has acquired a significant body of knowledge on the diamondiferous rocks of Guaniamo, including their style of occurrence, their petrographic and geochemical characteristics, their identity, and their geological age.

The diamondiferous rocks of Guaniamo are kimberlites which occur as sills and dykes. Their age is $710 \mathrm{Ma}$ and they are highly diamondiferous.

\section{Geological setting}

Guaniamo is located in the north - western part of the Guyana shield in an area of predominantly granitic basement with metamorphic ages of $\sim 1.8 \mathrm{Ga}$. The region forms part of the Cuchivero - Suapure block (Mendoza, 1972) which extends west to the Orinoco river and the frontier with Colombia, and east to the Caura river.

Within the Guaniamo zone itself, the zone of known kimberlite occurrence occurs within NW - trending foliated granites and granodiorites with ages of $\sim 1.8 \mathrm{Ga}$. Rhyolites and associated felsic tuffs have similar ages. An extensive suite of massive gabbro dykes and plugs was intruded at $\sim 1.6$ Ga (Gibbs and Barron, 1993). The southern part of the Guaniamo region is occupied by younger, massive granites with an age of $1.425 \mathrm{Ga}$ (U-Pb zircon age). Generally shallow dipping sediments of the Roraima formation unconformably overlie the basement rocks, with the closest Roraima outcrops lying $\sim 30 \mathrm{~km}$ south of the Guaniamo region (e.g., Cerro Yavi). Biotite - rich lamprophyre dykes, dated at $\sim 850 \mathrm{Ma}$ (Nixon et al., 1992), occur in kimberlite workings and are clearly cross cut by kimberlite. Kimberlite emplacement at $710 \mathrm{Ma}$ is the youngest intrusive event which has been observed so far in the Guaniamo region. Occasional diabase dykes have been observed but these are of unknown age.

\section{Style of occurrence}

Kimberlite has now been exposed at different times at $\sim 30$ sites in an area $\sim 10 \mathrm{~km}$ long and 5 $\mathrm{km}$ wide. At these sites weathered kimberlite occurs as low to moderate dip sills and dykes which range in thickness from a few $\mathrm{cm}$ to $3 \mathrm{~m}$. Strike directions are principally north - west with a subsidiary north - east direction. Dips are almost always to the east or south - east apart from local fluctuations in orientation and range from sub - horizontal to $\sim 50^{\circ}$. Through mapping of kimberlite localities and detailed positioning using GPS, it has become clear that the numerous kimberlite workings represent exposures of the up - dip portions of a large system of at least nine kimberlite sills. 


\section{Weathering characteristics and textures of Guaniamo kimberlites}

Outcropping kimberlite. Natural kimberlite outcrops are rare, occurring only where lateritisation has occurred. Lateritised kimberlite occurs where low dipping sills have been exposed over granitic pavements and forms a hard, nodular reddish - brown rock.

Kimberlite in the upper and mottled soil layers. Down dip from lateritised kimberlite there occurs a nodular soil where nodules and fragments of hard laterite are contained in a red - brown soil. Other, unlateritised, kimberlites form a dark red, massive, featureless soil which, taken in isolation, is difficult to recognise as kimberlite.

Kimberlite in the saprolite layer. In the saprolite layer the kimberlite shows full textural preservation. It is mostly clay - dominated but occasionally there are very hard, siliceous layers caused by low temperature silicification. Textures are perfectly preserved within the silicified layers. The following textural varieties of kimberlite may be distinguished:

(i) xenolith - rich. Xenoliths are from local rock types and of variable size and shape. In some cases the xenoliths form patterns, with long, linear xenoliths oriented parallel to the wall rock contact, separating zones of rounded xenoliths. Xenoliths often have alteration rims which weather to different colours. In some places the kimberlite may split to enclose metre - scale pieces of wall rock.

(ii) massive, fine grained. The kimberlite forms a clay which may be one of many colours including red, black, grey, green, yellow, brown, blue, and white. Clay pseudomorphed olivine phenocrysts and xenocrysts may be observed and also occasional phlogopite crystals.

(iii) coarsely macrocrystic. Coarse olivine xenocrysts, now pseudomorphed by clay minerals, are abundant and most kimberlite exposures have zones or layers where this texture is well developed.

(iv) magma pressed, olivine - rich. Coarse olivine xencrysts are very abundant and are preferentially aligned with their long axes perpendicular to the intrusion margin.

\section{Structural characteristics of kimberlite sills}

The kimberlite sills show no evidence for penetrative deformation. Field evidence suggests that the kimberlite sills were emplaced along existing structures, both of north - west and north - east orientations. Strong variations in kimberlite orientation occur at the intersections of these structures.

\section{Petrography and Mineralogy}

Thin section studies have revealed numerous textural features of the kimberlite, including both primary and alteration characteristics:

Coarse, porphyritic kimberlite. First generation olivine xenocrysts form up to $60 \%$ of the rock. Second generation olivine is usually finer grained and forms about $10 \%$ of the rock. Occasional coarse grained phlogopite laths may be present. Kelyphitic rims are common and may still have remnants of pyropes at their cores. The groundmass consists principally of phlogopite, with carbonate, serpentine, and opaques.

Aphyric kimberlite. This consists of a fine grained aggregate of phlogopite, carbonate, and opaques.

Alteration: serpentinisation and carbonatisation. Commonly olivine of both generations is replaced by scaly serpentine and microcrystalline carbonate.

Alteration: silicification. Complete replacement of kimberlite by microcrystalline silica is common and may be observed at most field localities. In addition, thin veinlets of opaline silica may be developed. In some samples the relict mesh texture of serpentinised olivine is preserved in totally silicifed grains, showing that silicification is later than serpentinisation and carbonatisation. 
Alteration: lateritisation. Lateritised kimberlite is brick red in colour and is characterised by flattened amoeboid channels, apparently linked in three dimensions. Electron microprobe analysis of relict spinels showed that they are compositionally identical to groundmass spinels from fresh kimberlite in Guaniamo, and to many other kimberlites.

Summary of Mineralogy. Kimberlitic high pressure minerals which have been identified include: olivine, pyrope, chrome diopside, chrome spinel, and phlogopite. Primary, magmatic minerals from the groundmass include: magnetite, $\mathrm{Mg}$ - rich titanomagnetite, and phlogopite. Minerals related to hydrothermal and hypogene alteration include: Fe hydroxides, carbonate, quartz, saponite, and serpentine.

\section{Geochemistry}

Nine samples of unweathered kimberlite drill core were analysed for major and trace elements. Contaminated samples are identified by relatively high $\mathrm{SiO}_{2}$ and low $\mathrm{MgO}$ contents probably representing a combination of the effects of granodiorite xenolith incorporation and alteration such as silicification. For comparison of the data for Guaniamo kimberlites with world averages and various compositional fields for different types of kimberlites, reference has been made to Mitchell (1986) and Taylor et al. (1994). The uncontaminated kimberlite samples have low $\mathrm{SiO}_{2}$ contents $(<37 \mathrm{wt} \%)$, very low $\mathrm{Al}_{2} \mathrm{O}_{3}$ values $(<5.2 \mathrm{wt} \%)$, and very low $\mathrm{Na}_{2} \mathrm{O}$ values $(<0.5 \mathrm{wt} \%$; one sample had $1.39 \mathrm{wt} \%)$. The other oxides have values within the accepted range for kimberlites and the $\mathrm{Na}_{2} \mathrm{O} / \mathrm{K}_{2} \mathrm{O}$ ratios are less than or equal to 0.50 .

Values for $\mathrm{Cr}, \mathrm{Co}, \mathrm{Ni}, \mathrm{V}, \mathrm{Cu}$, and $\mathrm{Zn}$ for Guaniamo kimberlites are within the ranges of values for kimberlites in general. Additional analytical work is in progress.

\section{Acknowledgements}

Information from various internal company reports and private reports from work conducted on a contract basis has been used in this paper. We acknowledge the following authors of these reports: N. Evenson, P. Hwang, D. Moser, D. Schulze, S. Sablukov, L. Sablukova and D. York.

\section{References}

Gibbs A. K., and Barron C. N., 1993, Geology of the Guiana shield, Oxford University Press, 246p.

Mendoza V., 1972, Geologia del area del Rio Suapure, Parte noroccidental del Escudo de Guyana, Estado Bolivar, Venezuela. IX Conferencia Inter - Guyana, p. 306-337.

Mitchell R. H., 1986, Kimberlites. Plenum Press.

Nixon P. H., Davies G. R., Rex D. C., and Gray A., 1992, Venezuela kimberlites. Journal of Volcanology and Geothermal Research, 50, p. 101-115.

Reid A. R., 1974, Proposed origin for Guianian diamonds. Geology, 2, p. 67-68.

Taylor W. R., Tompkins L. A., and Haggerty S. E., 1994, Comparative geochemistry of West African kimberlites: evidence for a micaceous kimberlite endmember of sublithospheric origin. Geochimica et Cosmochimica Acta, 58, p. 4017-4037. 